\title{
Effects of carbohydrate (CHO) and fat supplementation on CHO metabolism during prolonged exercise.
}

Citation for published version (APA):

Jeukendrup, A. E., Saris, W. H. M., Brouns, F. J. P. H., Halliday, D., \& Wagenmakers, A. J. M. (1996). Effects of carbohydrate $(\mathrm{CHO})$ and fat supplementation on $\mathrm{CHO}$ metabolism during prolonged exercise. Metabolism-Clinical and Experimental, 45, 915-921. https://doi.org/10.1016/S0026-0495(96)90169-9

Document status and date:

Published: 01/01/1996

DOI:

10.1016/S0026-0495(96)90169-9

Document Version:

Publisher's PDF, also known as Version of record

Please check the document version of this publication:

- A submitted manuscript is the version of the article upon submission and before peer-review. There can be important differences between the submitted version and the official published version of record.

People interested in the research are advised to contact the author for the final version of the publication, or visit the DOI to the publisher's website.

- The final author version and the galley proof are versions of the publication after peer review.

- The final published version features the final layout of the paper including the volume, issue and page numbers.

Link to publication

\footnotetext{
General rights rights.

- You may freely distribute the URL identifying the publication in the public portal. please follow below link for the End User Agreement:

www.umlib.nl/taverne-license

Take down policy

If you believe that this document breaches copyright please contact us at:

repository@maastrichtuniversity.nl

providing details and we will investigate your claim.
}

Copyright and moral rights for the publications made accessible in the public portal are retained by the authors and/or other copyright owners and it is a condition of accessing publications that users recognise and abide by the legal requirements associated with these

- Users may download and print one copy of any publication from the public portal for the purpose of private study or research.

- You may not further distribute the material or use it for any profit-making activity or commercial gain

If the publication is distributed under the terms of Article $25 \mathrm{fa}$ of the Dutch Copyright Act, indicated by the "Taverne" license above, 


\title{
Effects of Carbohydrate (CHO) and Fat Supplementation on CHO Metabolism During Prolonged Exercise
}

\author{
Asker E. Jeukendrup, Wim H.M. Saris, Fred Brouns, David Halliday, and Anton J.M. Wagenmakers
}

The aim of the study was to examine carbohydrate $(\mathrm{CHO})$ utilization in subjects receiving $\mathrm{CHO}$ or $\mathrm{CHO}+$ medium-chain triglycerides (MCT) supplements during 180 minutes of exercise at $\mathbf{5 0 \%}$ maximal aerobic work rate ([Wmax] $57 \%$ maximal oxygen consumption [ $\left.\mathrm{VO}_{2} \mathrm{max}\right]$ ). In a double-blind crossover design, nine trained athletes cycled four times. Subjects received a bolus of $4 \mathrm{~mL} \cdot \mathrm{kg}^{-1}$ at the start and $2 \mathrm{~mL} \cdot \mathrm{kg}^{-1}$ every 20 minutes during exercise of either a 150-g $\cdot \mathrm{L}^{-1} \mathrm{CHO}$ solution (CHO trial), an equicaloric 70 energy $\%$ (en $\%$ ) CHO-30 en\% MCT suspension containing $29 \mathrm{~g} \mathrm{MCT}$ (CHO + MCT trial), or a 150-g $\cdot \mathrm{L}^{-1} \mathrm{CHO}$ (high-CHO [HCHO]) solution plus $29 \mathrm{~g} \mathrm{MCT} \mathrm{(HCHO} \mathrm{+} \mathrm{MCT} \mathrm{trial).} \mathrm{A} \mathrm{fourth} \mathrm{trial} \mathrm{consisted} \mathrm{of} \mathrm{a}{ }^{13} \mathrm{C}$-background control trial (CON). The four trials were randomized. Before and after the exercise bout, muscle biopsies were taken from the quadriceps muscle and muscle glycogen levels were determined. During exercise, breath samples were collected for estimation of exogenous and endogenous CHO oxidation. No significant differences were detected in glycogen breakdown among the trials (277 \pm 1414 $\mathrm{mmol} \cdot \mathrm{kg}$ dry weight ${ }^{-1} \mathrm{CHO}, 249 \pm 20 \mathrm{CHO}+\mathrm{MCT}$, and $240 \pm 18 \mathrm{HCHO}+\mathrm{MCT}$ ) or in the respiratory exchange ratio during exercise. Mean exogenous $\mathrm{CHO}$ oxidation rates during the final hour of exercise were $0.79,0.63$, and $0.73 \mathrm{~g} \cdot \mathrm{min}^{-1}$, respectively. No differences were observed between the trials regarding exogenous or endogenous CHO oxidation. Plasma free fatty acid (FFA) concentrations were elevated during exercise to a level of approximately $500 \mu \mathrm{mol} \cdot \mathrm{L}^{-1}$ and were comparable in all trials, whereas plasma ketone concentrations significantly increased after MCT ingestion as compared with the $\mathrm{CHO}$ trial. It is concluded that $29 \mathrm{~g}$ MCT co-ingested with $\mathrm{CHO}$ during 180 minutes of exercise does not influence $\mathrm{CHO}$ utilization or glycogen breakdown.

Copyright $\odot 1996$ by W.B. Saunders Company

O RAL INGESTION of carbohydrate (CHO) during exercise has been shown to better maintain plasma glucose levels ${ }^{1}$ and high rates of plasma glucose oxidation, ${ }^{2}$ resulting in improved endurance capacity. ${ }^{1}$ Oxidation rates of orally ingested $\mathrm{CHO}$ have never been observed to be higher than 1.0 to $1.1 \mathrm{~g} \cdot \mathrm{min}^{-1}$, which seems to be the maximum oxidation rate. Even ingestion rates of up to 2 $\mathrm{g} \cdot \mathrm{min}^{-1}$ during exercise at $70 \%$ maximal oxygen consumption $\left(\dot{\mathrm{V}}_{2} \max \right)$ resulted in oral glucose oxidation rates of no more than $1 \mathrm{~g} \cdot \mathrm{min}^{-1}{ }^{3}$ To supply an additional exogenous energy source for the working muscle, substrates other than or in addition to $\mathrm{CHO}$ might be ingested. One potential candidate for such an energy source could be mediumchain triglycerides (MCT). MCT have been shown to be rapidly hydrolyzed, absorbed, ${ }^{4}$ and subsequently oxidized. $5,6,6 a$ In addition, a preliminary study showed that MCT co-ingested with $\mathrm{CHO}$ do not inhibit gastric emptying. ${ }^{7}$ Moreover, it has been suggested that MCT ingestion may improve exercise performance by elevating plasma free fatty acid (FFA) levels and sparing muscle glycogen. ${ }^{8}$ Several studies have reported this relationship between increased availability of plasma FFA, reduced rate of muscle glycogen breakdown, ${ }^{9-13}$ and delayed onset of exhaustion. $9,10,13$

However, increased supply and subsequent oxidation of FFA or ketone bodies have been shown to result in an inhibition of plasma glucose utilization, ${ }^{14,15}$ as well as overall CHO utilization. From these observations, one might hypothesize that increasing the FFA availability by oral fat intake may also limit the utilization of the exogenously supplied CHO.

The aim of the present study therefore was to investigate the effects of MCT co-ingested with $\mathrm{CHO}$ on exogenous and endogenous $\mathrm{CHO}$ utilization during prolonged exercise, and to determine what effect this regimen had on muscle glycogen breakdown. The CHO + MCT mixture was based on the CHO + MCT suspension that emptied most rapidly from the stomach in a previous comparative study. ${ }^{7}$ The amount ingested was based on the maximal amount of MCT that could be ingested without causing gastrointestinal problems.

\section{SUBJECTS AND METHODS}

\section{Subjects}

Nine male trained triathletes or cyclists aged (mean \pm SEM) $26.0 \pm 5.0$ years with a weight of $75.7 \pm 4.3 \mathrm{~kg}$, height $185 \pm 8 \mathrm{~cm}$, maximal aerobic work rate (Wmax) $5.48 \pm 0.24 \mathrm{~W} \cdot \mathrm{kg}^{-1}, \dot{V}_{2} \max$ $64.7 \pm 2.3 \mathrm{~mL} \cdot \mathrm{kg}^{-1}$, and maximal heart rate $194 \pm 5.3 \mathrm{bpm}$ participated in this study. The nature and the risks of the experimental procedures were explained to the subjects, and their written informed consent was obtained. The study was approved by the local medical ethics committee.

\section{Pretrials}

Wmax was measured on an electronically braked ergometer (Lode Excalibur, Groningen, The Netherlands) during an incremental exhaustive exercise test ${ }^{16} 1$ week before the first experimental trial. The results of this initial test were used to determine $50 \%$ Wmax, which was later used in the experimental trials.

\section{Experimental Trials}

Nine subjects performed four trials, each separated by at least 7 days. A trial consisted of 180 minutes of cycling at $50 \%$ Wmax $\left(57 \% \pm 2 \% \dot{\mathrm{VO}}_{2} \mathrm{max}\right)$. Drinks were given in a randomized order

From the Department of Human Biology, Nutrition Research Centre, University of Limburg, Maastricht, The Netherlands.

Submitted December 12, 1995; accepted January 18, 1996.

Supported by an Isostar Research Grant from Sandoz Nutrition, Berne, Switzerland.

Address reprint requests to Asker E. Jeukendrup, Department of Human Biology, University of Limburg, PO Box 616, 6200 MD Maastricht, The Netherlands.

Copyright $@ 1996$ by W.B. Saunders Company

0026-0495/96/4507-002/\$03.00/0 
and double-blind; all drinks were vanilla-flavored (Sandoz Nutrition, Berne, Switzerland). Subjects abstained from training and were instructed to consume a similar diet for the 3 days before each trial. In addition, they were instructed not to consume any products with a high natural abundance of ${ }^{13} \mathrm{C}$ during the entire experimental period.

\section{Protocol}

Subjects reported to the laboratory at 8:00 AM after an overnight fast, and a standardized breakfast of two crackers with cheese was provided ( $14 \mathrm{~g} \mathrm{CHO}, 4 \mathrm{~g}$ fat, and $6 \mathrm{~g}$ protein). A Teflon catheter (Baxter Quick Cath; Uden, The Netherlands) was inserted into an antecubital vein, and at 8:30 AM a resting blood sample was drawn. Also, a muscle biopsy was taken from the lateral part of the vastus lateralis. Resting breath gases were collected for measurement of oxygen consumption (2900 analyzer; SensorMedics, Anaheim, CA), and vacutainer tubes were filled directly from the mixing chamber in duplicate to determine the ${ }^{13} \mathrm{C} /{ }^{12} \mathrm{C}$ ratio in expired $\mathrm{CO}_{2}$. At 8:50 AM, subjects started cycling for 10 minutes at $100 \mathrm{~W}$ as a warm-up. At 9:00 AM, exercise intensity was increased to $50 \%$ Wmax for 180 minutes. Blood samples were drawn at 30-minute intervals until the end of exercise. Expiratory gases were collected every 15 minutes. Two subjects were tested on the same day, starting the protocol 10 minutes apart. Directly after the exercise bout, a second muscle biopsy was taken $2 \mathrm{~cm}$ proximal to the first biopsy.

\section{Drinks}

Subjects received a bolus of $4 \mathrm{~mL} \cdot \mathrm{kg}^{-1}$ at the start $(\mathrm{t}=0)$ and 2 $\mathrm{mL} \cdot \mathrm{kg}^{-1}$ every 20 minutes during exercise of either a $15 \% \mathrm{CHO}$ solution (CHO) or an equicaloric $\mathrm{CHO}+\mathrm{MCT}$ suspension $([\mathrm{CHO}+\mathrm{MCT}] 70$ energy\% [en\%] as CHO [149 $\mathrm{g} / 180 \mathrm{~min}]$ and $30 \mathrm{en} \%$ as MCT [ $29 \mathrm{~g} / 180 \mathrm{~min}])$. To study the effect of MCT added to the CHO instead of the equicaloric CHO + MCT suspension, a third trial (high-CHO [HCHO] + MCT) was included in which a suspension was ingested containing the same amount of CHO (214 $\mathrm{g} / 180 \mathrm{~min}$ ) as in the CHO trial and the same amount of MCT (29 $\mathrm{g} / 180 \mathrm{~min}$ ) as in the CHO + MCT and MCT trials. Therefore, it could be investigated whether differences between the $\mathrm{CHO}+$ MCT trial and the CHO trial are due to the MCT or to the differential amount of $\mathrm{CHO}$. The $\mathrm{CHO}$ in these trials were corn-derived long-chain glucose polymers of high natural ${ }^{13} \mathrm{C}$ abundance $\left(-11.31 \delta\right.$ per mil $v$ PDB, $0.0111101{ }^{13} \mathrm{C} /{ }^{12} \mathrm{C}$ ratio). To enable correction for possible shifts in background ${ }^{13} \mathrm{C}$ enrichment during exercise, a fourth trial was included in which tapiocaderived long-chain glucose polymers of low ${ }^{13} \mathrm{C}$ natural abundance $\left(-26.12 \delta\right.$ per mil $v \mathrm{PDB}, 0.0109437{ }^{13} \mathrm{C} /{ }^{12} \mathrm{C}$ ratio; Sandoz Nutrition; Berne, Switzerland) were ingested (CON). This CON trial was used only for ${ }^{13} \mathrm{C}$-background measurements; no other measurements are presented.
MCT contained fatty acids with a chain length of C8 (Estasan GT8-99; Unichema, Barcelona, Spain) and had a ${ }^{13} \mathrm{C}$ enrichment of $-29.81 \delta$ per mil versus PDB $\left(0.0109222{ }^{13} \mathrm{C} /{ }^{12} \mathrm{C}\right.$ ratio $)$. $\mathrm{NaCl}(20$ $\mathrm{mmol} \cdot \mathbf{L}^{-1}$ ) was added to all drinks. Meal temperature was kept constant at $20^{\circ} \mathrm{C}$.

\section{Analysis}

Blood $(10 \mathrm{~mL})$ was collected into EDTA-containing tubes and centrifuged for 4 minutes. Aliquots of plasma were frozen immediately in liquid nitrogen and stored at $-40^{\circ} \mathrm{C}$ until analyses of glucose (Uni Kit III, 0710970; La Roche, Basel, Switzerland), lactate, ${ }^{17} \beta$-hydroxybutyrate, ${ }^{18}$ FFA (Wako FFA-C test kit; Wako Chemicals, Neuss, Germany), and glycerol (GPO-trinder 337; Sigma, St Louis, MO), which were performed with the COBAS BIO analyzer (La Roche). Muscle biopsies were freeze-dried, and glycogen content was assayed spectrophotometrically after hydrolysis with $\mathrm{HCl} .{ }^{19}$ Glycogen concentration was expressed as millimoles of glycosyl units per kilogram dry weight of tissue. Total energy expenditure and oxidation rates of total fat, total $\mathrm{CHO}$, and exogenous MCT were calculated from indirect calorimetry (respiratory quotient and $\left.\dot{\mathrm{VO}}_{2}\right)$ and stable-isotope measurements $\left({ }^{13} \mathrm{CO}_{2} /\right.$ ${ }^{12} \mathrm{CO}_{2}$ ) (GC continuous-flow IRMS; Finnigan MAT 252, Bremen, Germany). Enrichments of the substrates (in drinks) were measured with an elemental analyzer-IRMS combination (Carlo-Erba on-line [EA 1108CHN; Fisons, Milan, Italy] connected to the Finnigan MAT 252).

\section{Calculations}

$\mathrm{CHO}$ and fat oxidation rates were calculated from $\dot{\mathrm{VCO}}_{2}$ and $\dot{\mathrm{VO}}_{2}$ using the nonprotein respiratory quotient ${ }^{20}$ : $\mathrm{CHO}$ oxidation $=$ $4.585 \dot{\mathrm{VCO}}_{2}-3.226 \dot{\mathrm{Vo}}_{2}$, and fat oxidation $=1.695 \dot{\mathrm{V}}_{2}-1.701$ $\dot{\mathrm{V}} \mathrm{CO}_{2}$. Isotopic enrichment of expired air was expressed as the delta per mil difference between the ${ }^{13} \mathrm{C} /{ }^{12} \mathrm{C}$ ratio of the sample and a known laboratory reference standard according to the formula, $\delta$ ${ }^{13} \mathrm{C}($ per mil $)=\left(\left[{ }^{13} \mathrm{C} /{ }^{12} \mathrm{C}\right.\right.$ sample $] /\left[{ }^{13} \mathrm{C} /{ }^{12} \mathrm{C}\right.$ standard $\left.]-1\right) \times 10^{3}$. The $\delta^{13} \mathrm{C}$ was then related to the international standard, Pee Dee Bellemnitella (PDB-I). The amount of CHO oxidized was calculated according to the formula, exogenous $\mathrm{CHO}$ oxidation $=$ $\dot{\mathrm{V}} \mathrm{CO}_{2} \cdot(\delta$ ref $-\delta$ exp $) /(\delta$ ref $-\delta$ ing $) \cdot 1 / k$, in which $\delta$ ref is the ${ }^{13} \mathrm{C}$ enrichment of expired air in the reference test CON (background), $\delta$ exp is the ${ }^{13} \mathrm{C}$ enrichment of expired $\mathrm{CO}_{2}$ during exercise with $\mathrm{CHO}(+\mathrm{MCT})$ ingestion at different time points, $\delta$ ing is the ${ }^{13} \mathrm{C}$ enrichment of the $\mathrm{CHO}$ in the ingested CHO + MCT suspension, and $\mathrm{k}$ is the amount of $\mathrm{CO}_{2}$ (in liters) produced via oxidation of 1 gram glucose $\left(\mathrm{k}=0.7466 \mathrm{~L} \mathrm{CO}_{2} / \mathrm{g}\right.$ glucose $)$.

In the present study and in previous studies from our laboratory, ${ }^{3,5,21,22}$ it was shown that instructing the subjects not to eat any products of high natural ${ }^{13} \mathrm{C}$ abundance during the experimental period was effective in reducing the background shift (change in ${ }^{13} \mathrm{CO}_{2}$ ) from endogenous substrate stores. ${ }^{22}$ However, although the

Table 1. $\mathrm{V}_{2}$ and Respiratory Exchange Ratio (mean \pm SEM) During 3 Hours of Cycling Exercise at $57 \% \mathrm{Vo}_{2}$ max with ingestion of $\mathrm{CHO}$, $\mathrm{CHO}+$ MCT, or $\mathrm{HCHO}+$ MCT

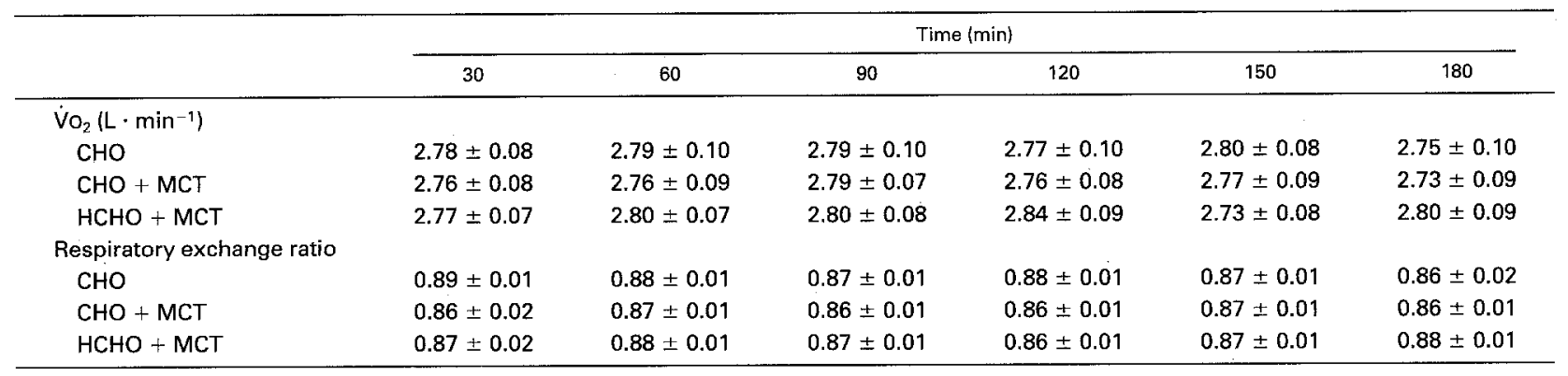

NOTE. No significant differences were observed among the trials or over time. 


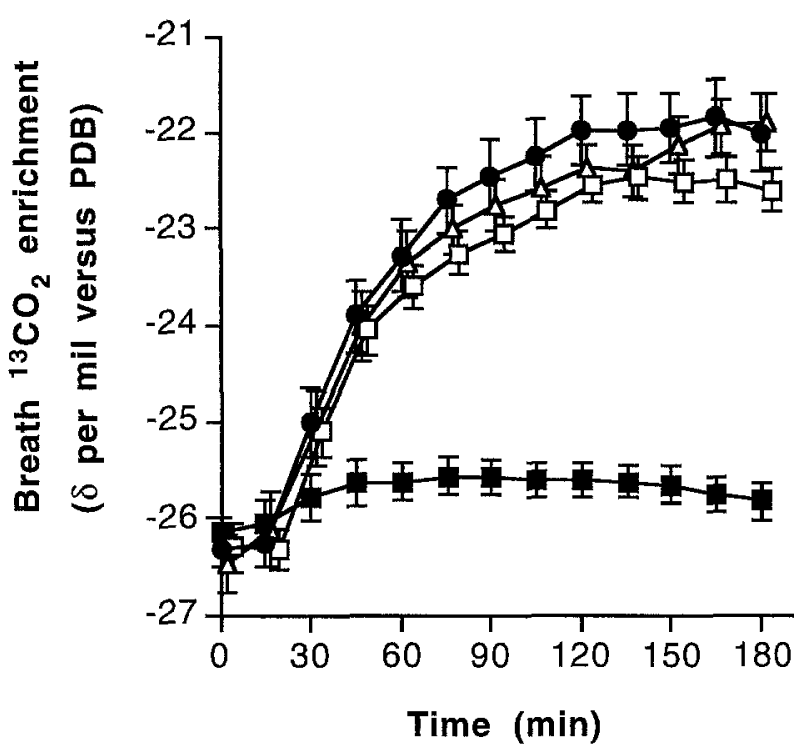

Fig 1. Breath ${ }^{13} \mathrm{CO}_{2}$ enrichment during exercise in (e) $\mathrm{CHO}$, (ㅁ) $\mathrm{CHO}+\mathrm{MCT}$, and $(\triangle) \mathrm{HCHO}+\mathrm{MCT}$ trials and during the (E) CON trial used for background correction (mean $\pm S E M, n=6$ ).

background shift was small in the present study, background correction was made by using the ${ }^{13} \mathrm{C}$ enrichment of breath samples in the CON trial. We assumed that the low ${ }^{13} \mathrm{C}$ abundance of MCT was similar enough to the ${ }^{13} \mathrm{C}$ abundance of endogenous substrate stores, so that the observed changed in ${ }^{13} \mathrm{CO}_{2}$ production can be attributed to the $\mathrm{CHO}$ and not to the MCT. To check whether this was a valid assumption, we performed a pilot study in which subjects underwent the same protocol described herein while ingesting $\mathrm{CHO}$ or $\mathrm{CHO}+\mathrm{MCT}$ beverages containing tapiocaderived CHO ( $-26.12 \delta$ per mil $v$ PDB). Any difference between the two trials could be attributed to the lower ${ }^{13} \mathrm{C}$ abundance of the MCT $\left(-29.81 \delta\right.$ per mil $v$ PDB). However, the ${ }^{13} \mathrm{C}$ enrichment of expired $\mathrm{CO}_{2}$ was identical in both conditions at all time points, and thus, we concluded that the low ${ }^{13} \mathrm{C}$ abundance of MCT would not influence the calculated exogenous $\mathrm{CHO}$ oxidation rates in the present study.

Another methodological consideration when using ${ }^{13} \mathrm{CO}_{2}$ in expired gases to calculate exogenous substrate oxidation is the trapping of exogenous ${ }^{13} \mathrm{CO}_{2}$ in the bicarbonate pool, a very large

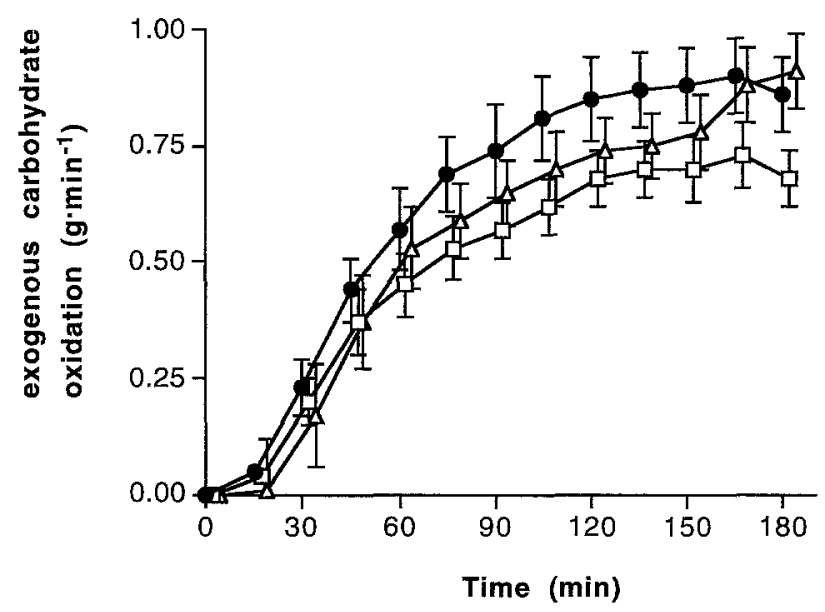

Fig 2. Exogenous MCT oxidation rates over 180 minutes of exercise (mean \pm SEM, $n=6$ ). Symbols are as in Fig 1 .
Table 2. Oxidation of Endogenous and Exogenous Substrates (in grams) Over the 60- to 120-minute and 120- to 180-Minute Periods (mean \pm SEM)

\begin{tabular}{lccc}
\hline \multicolumn{1}{c}{ Interval } & $\mathrm{CHO}$ & $\mathrm{CHO}+\mathrm{MCT}$ & $\mathrm{HCHO}+\mathrm{MCT}$ \\
\hline $60-120$ & & & \\
CHO & $132.2 \pm 11.4$ & $122.5 \pm 10.3$ & $127.3 \pm 10.3$ \\
Exogenous & $44.2 \pm 3.7$ & $34.2 \pm 3.7$ & $38.6 \pm 5.0$ \\
Endogenous & $88.0 \pm 8.3$ & $88.3 \pm 7.3$ & $88.7 \pm 9.3$ \\
Fat & $34.3 \pm 3.7$ & $37.5 \pm 3.7$ & $36.7 \pm 3.2$ \\
$120-180$ & & & \\
CHO & $124.1 \pm 12.8$ & $119.6 \pm 9.8$ & $130.8 \pm 9.9$ \\
Exogenous & $50.3 \pm 3.2$ & $41.5 \pm 5.0$ & $48.5 \pm 4.8$ \\
Endogenous & $73.8 \pm 9.9$ & $78.1 \pm 6.5$ & $82.3 \pm 9.3$ \\
Fat & $33.8 \pm 4.2$ & $38.7 \pm 3.0$ & $35.1 \pm 3.1$ \\
\hline
\end{tabular}

NOTE. No significant differences in substrate utilization were observed among the trials or time periods.

and slowly exchanging pool in which some $\mathrm{CO}_{2}$ arising from decarboxylation of energy substrates is temporarily trapped..$^{23}$ However, during exercise, $\mathrm{CO}_{2}$ production increases severalfold so that a physiological steady-state situation will occur and ${ }^{13} \mathrm{CO}_{2}$ in expired air will be rapidly equilibrated with the ${ }^{13} \mathrm{CO}_{2} / \mathrm{H}^{13} \mathrm{CO}_{3}^{-}$ pool. The dilution of ${ }^{13} \mathrm{CO}_{2}$ becomes negligible and recovery of ${ }^{13} \mathrm{CO}_{2}$ approaches $100 \%$ after 60 minutes of exercise. ${ }^{38}$ Therefore, in the present study, data from the initial 60 minutes were not used for calculation of exogenous MCT oxidation.

\section{Gastrointestinal Discomfort}

A questionnaire assessing gastrointestinal discomfort was provided after each exercise test. Subjects had to score the following items on a scale from 1 to $5(1=$ not at all to $5=$ very severe $)$ : nausea, intestinal cramps, belching, vomiting, diarrhea, flatulence, stomach ache, abdominal pressure, and eructation.

\section{Statistics}

ANOVA for repeated measures was used to compare differences in substrate utilization and in blood-related parameters

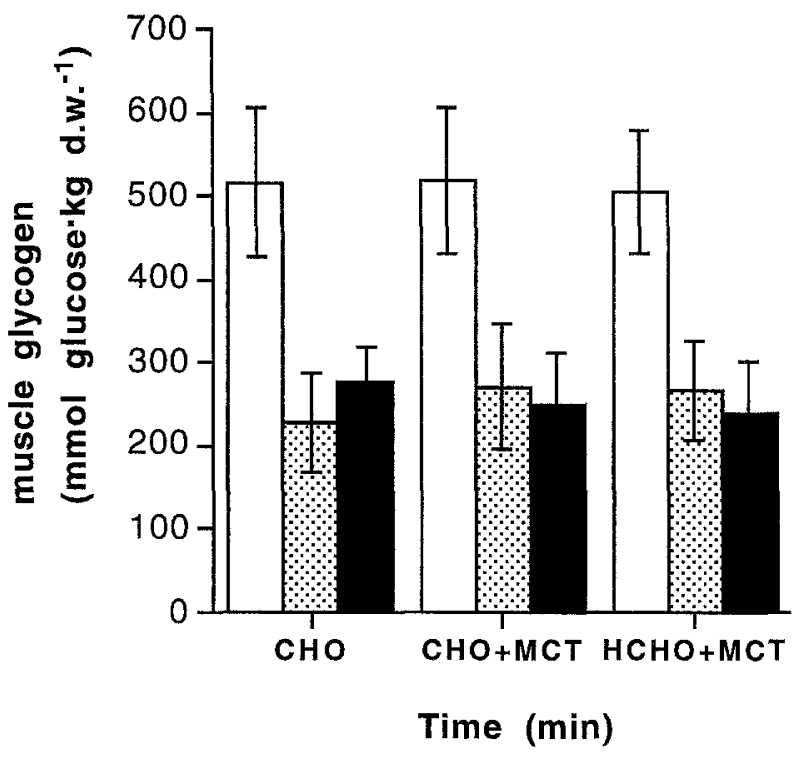

Fig 3. ( $\square$ ) Preexercise and (혀) postexercise glycogen concentrations and ( $\mathrm{G}$ ) glycogen breakdown (decrease) for the $\mathrm{CHO}, \mathrm{CHO}+$ $M C T$, and HCHO + MCT trials. No significant differences were observed among the trials (mean $\pm S E M, n=6$ ). 

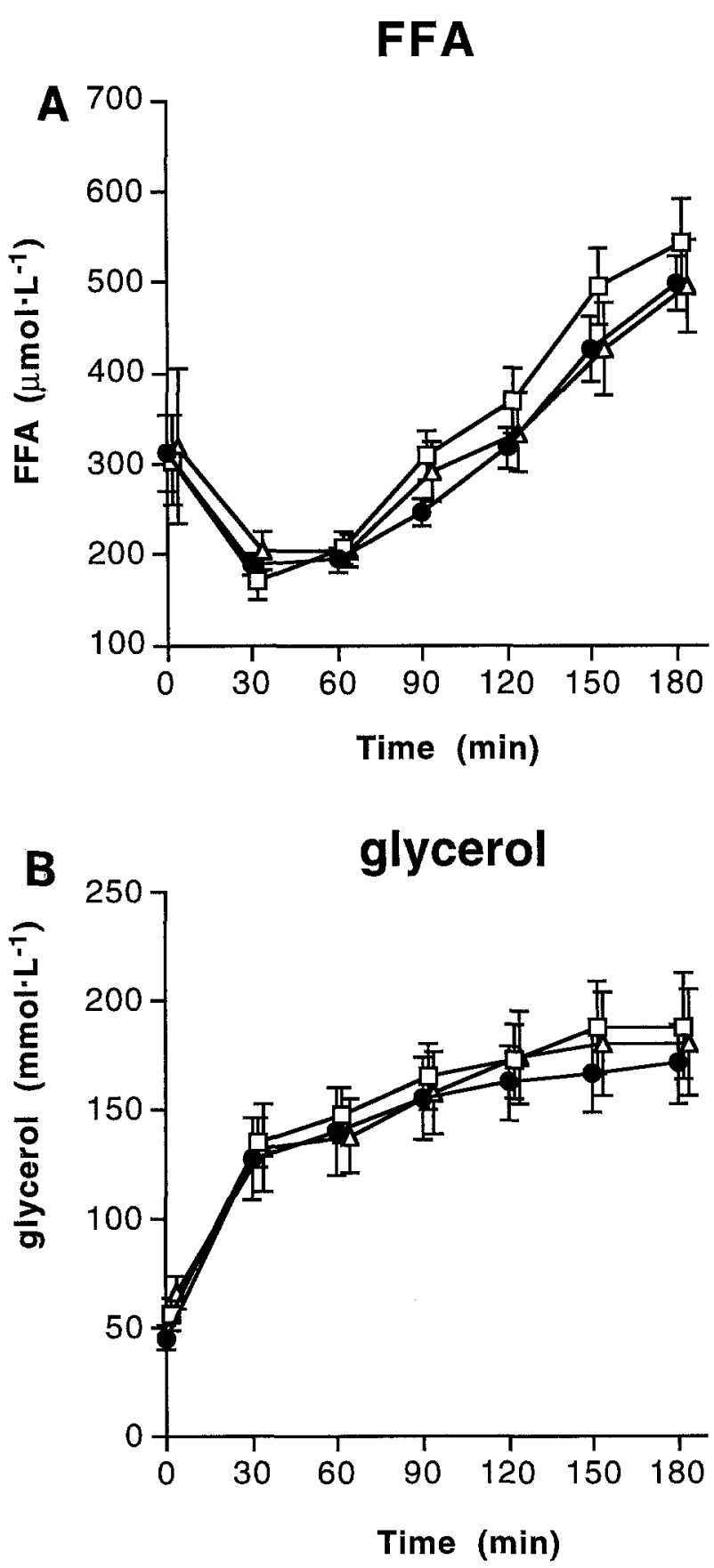

among the $\mathrm{CHO}, \mathrm{CHO}+\mathrm{MCT}$, and $\mathrm{HCHO}+\mathrm{MCT}$ trials. A Scheffé post hoc test was used in the event of a significant $(P<.05)$ $F$ ratio. All results are expressed as the mean \pm SEM.

\section{RESULTS}

\section{Breath Analysis}

Oxygen consumption (Table 1) during exercise was relatively constant, with exercise intensity of the subjects maintained at close to $57 \% \mathrm{VO}_{2} \mathrm{max}$ and not significantly different among the trials. The respiratory exchange ratio also was not significantly different among the trials.

The mean ${ }^{13} \mathrm{C}$ enrichment of the resting breath samples

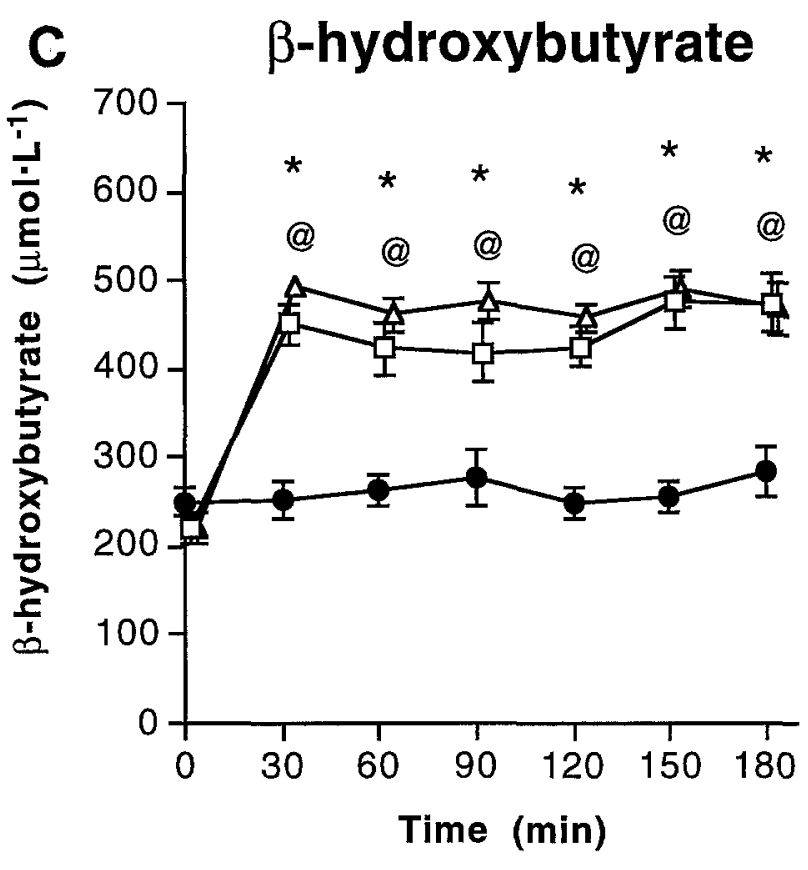

Fig 4. Plasma (A) FFA, (B) glycerol, and (C) B-hydroxybutyrate concentrations during exercise for the $\mathrm{CHO}, \mathrm{CHO}+\mathrm{MCT}$, and HCHO + MCT trials. *Significant difference $(P<.05)$ between $\mathrm{CHO}$ and $\mathrm{CHO}+\mathrm{MCT}$ (mean \pm SEM, $n=6$ ). Symbols are as in Fig 1.

was $-26.36 \pm 0.25 \delta$ per mil versus $\operatorname{PDB}\left(0.0109410^{13} \mathrm{C} /{ }^{12} \mathrm{C}\right.$ ratio). Changes in the isotopic composition of expired $\mathrm{CO}_{2}$ in response to exercise are depicted in Fig 1. During CON (with ingestion of $\mathrm{CHO}$ of low ${ }^{13} \mathrm{C}$ natural abundance), there was a small nonsignificant increase of ${ }^{13} \mathrm{C}$ in the expired air ( 0.2 to $0.6 \delta$ per mil $v$ PDB). In the $\mathrm{CHO}(+\mathrm{MCT})$ trials, the increase in ${ }^{13} \mathrm{C}$ was significant, reaching a difference of 3 to $4 \delta$ per mil versus PDB toward the end of 180 minutes' exercise (compared with resting breath sample; Fig 1). Exogenous CHO oxidation increased during the first hour and leveled off during the final 90 minutes (Fig 2). At the end of the exercise bout, exogenous CHO oxidation 
rates were $0.89,0.73$, and $0.91 \mathrm{~g} \cdot \mathrm{min}^{-1}$ for $\mathrm{CHO}, \mathrm{CHO}+$ $\mathrm{MCT}$, and $\mathrm{HCHO}+\mathrm{MCT}$, respectively. Mean oxidation rates over the 60 - to 180 -minute period were $0.79,0.63$, and $0.73 \mathrm{~g} \cdot \mathrm{min}^{-1}$, respectively. Exogenous CHO oxidation tended to be slightly lower in the $\mathrm{CHO}+\mathrm{MCT}$ trial than in the $\mathrm{CHO}$ trial. However, this difference did not reach statistical significance. It was estimated that during the 60 to 180 -minute period in the $\mathrm{CHO}$ trial, $94.5 \mathrm{~g}$ exogenous CHO was oxidized, versus $75.7 \mathrm{~g}$ in $\mathrm{CHO}+\mathrm{MCT}$ and $87.1 \mathrm{~g}$ in $\mathrm{HCHO}+\mathrm{MCT}$. The amounts of $\mathrm{CHO}$ (exogenous and endogenous) and fat oxidation during the second and third hour of exercise are presented in Table 2). Energy expenditure was comparable in all trials.

\section{Muscle Glycogen}

Preexercise muscle glycogen concentrations were comparable among the trials: $516 \pm 32,518 \pm 30$, and $505 \pm 26$ mmol glucose $\cdot \mathrm{kg}$ dry weight $(\mathrm{dw})^{-1}$ for $\mathrm{CHO}, \mathrm{CHO}+$ MCT, and $\mathrm{HCHO}+\mathrm{MCT}$, respectively. Muscle glycogen levels decreased significantly in the three trials: $277 \pm 14$ mmol glucose $\cdot \mathrm{kg} \mathrm{dw}^{-1}$ for $\mathrm{CHO}, 249 \pm 20$ for $\mathrm{CHO}+$ MCT, and $240 \pm 18$ for $\mathrm{HCHO}+\mathrm{MCT}$. Glycogen breakdown was not significantly different among the three trials (Fig 3).

\section{Plasma Variables}

Compared with rest, plasma FFA levels were decreased after $\mathbf{3 0}$ minutes of exercise and were significantly elevated during the final 30 minutes of exercise (Fig 4A). No differences in plasma FFA levels were observed among the trials. There was a significant increase in plasma glycerol levels after 30 minutes in all trials, but no differences were observed among the three trials (Fig 4B). Plasma $\beta$-hydroxybutyrate concentrations increased to approximately 500 $\mu \mathrm{mol} \cdot \mathrm{L}^{-1}$ during the first 30 minutes in the $\mathrm{CHO}+\mathrm{MCT}$ and $\mathrm{HCHO}+\mathrm{MCT}$ trials; thereafter, concentrations remained stable (Fig $4 \mathrm{C}$ ). In the $\mathrm{CHO}$ trial, no changes in $\beta$-hydroxybutyrate were observed throughout exercise. Plasma glucose levels were maintained during exercise (Fig 5A), whereas plasma lactate concentrations tended to decrease as compared with the resting value (Fig $5 \mathrm{~B}$ ). No differences were observed in plasma glucose or lactate concentrations between the trials.

\section{Gastrointestinal Discomfort}

Subjects reported some gastrointestinal discomfort in all tests. The occurrence and severity (mean score, 2.8) of the complaints were not different among the trials. Most frequently reported were intestinal cramps, nausea, and belching.

\section{DISCUSSION}

\section{Muscle Glycogen and Plasma FFA}

It has been reported in several studies that increased availability of plasma FFA resulted in muscle glycogen sparing ${ }^{9-13,24}$ and hence increased performance. ${ }^{10}$ In humans, plasma FFA levels have been elevated by injecting
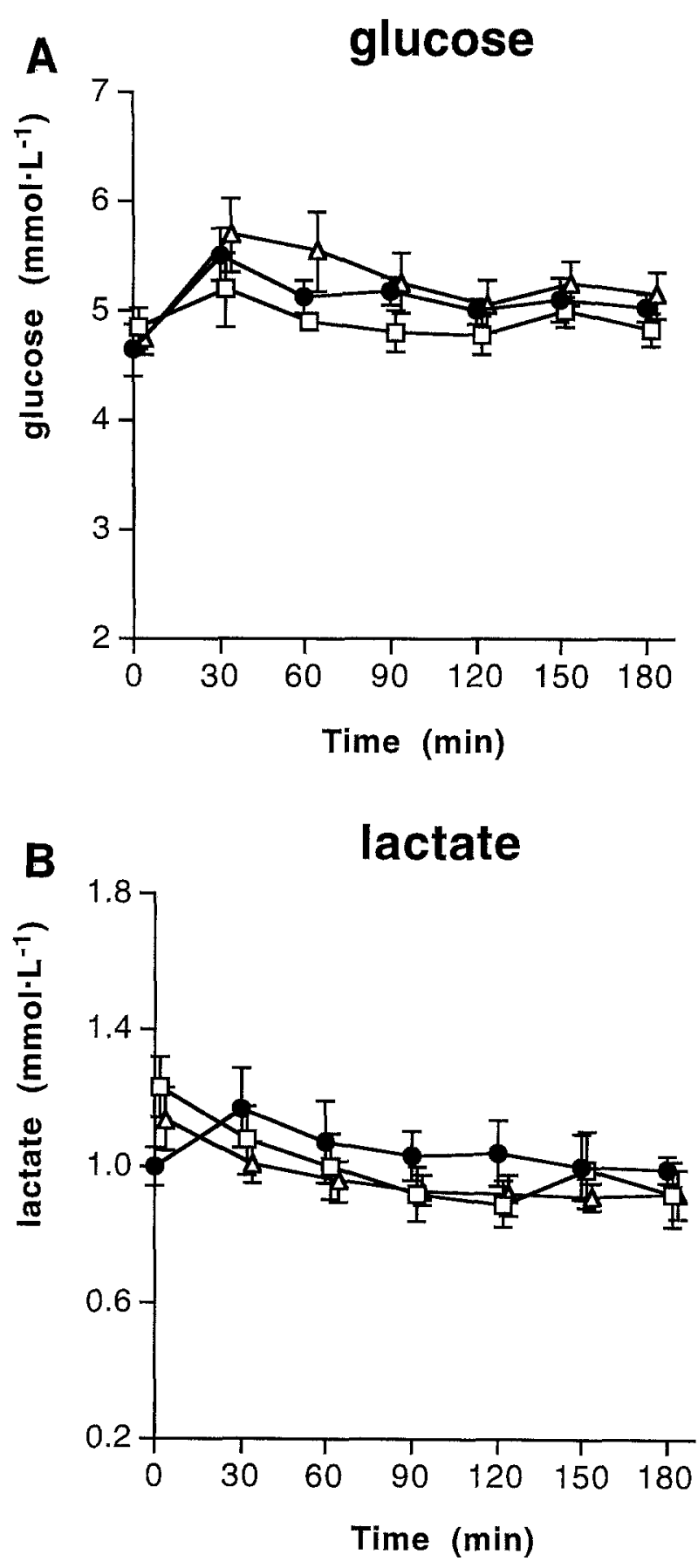

Fig 5. Plasma (A) glucose and (B) lactate concentrations during exercise for the CHO, CHO + MCT, and HCHO + MCT trials. *Significant difference between CHO and CHO + MCT $(P<.05)$. @Significant difference between $\mathrm{CHO}$ and $\mathrm{HCHO}+\mathrm{MCT}(P<.05)($ mean \pm SEM, $n=6$ ).

heparin, which stimulates lipoprotein lipase activity, after feeding subjects a high-fat meal (long-chain fatty acids) or infusing a triglyceride emulsion (Intralipid). ${ }^{9,13,24}$ In these studies, a glycogen-sparing effect was observed when FFA availability was high. Although the infusion of fats and consumption of triglycerides in combination with an injection of heparin are interesting approaches to test the 
interaction between $\mathrm{CHO}$ and fat metabolism during exercise, this method has little practical value. It has therefore been suggested that ingestion of MCT will increase FFA availability. ${ }^{5,6,8,25-28}$ MCT are delivered into the blood more rapidly than ingested long-chain triglycerides, $4,29,30$ and can cross the mitochondrial membrane without carnitine. ${ }^{31}$ Therefore, it has been argued that MCT might be a readily available energy source for the working muscle. In addition, it has been suggested that MCT might spare muscle glycogen and improve time-trial cycling performance. ${ }^{8}$ In the present study and in a recent study with a similar experimental protocol, ${ }^{5}$ although the maximally tolerable amount of MCT was ingested, it did not affect plasma FFA levels. Hence, no effect on muscle glycogen utilization was observed. This is in agreement with the only other available study in which muscle glycogen concentrations were determined after MCT ingestion. ${ }^{26}$ In it, MCT were ingested 1 hour before exercise and did not result in glycogen-sparing during 1 hour of exercise at $60 \% \dot{\mathrm{VO}}_{2} \max$. It may be that the amount of MCT provided was too small to influence plasma FFA concentrations, or that medium-chain fatty acids are oxidized rapidly in the liver and/or in skeletal muscle so that plasma FFA concentration remains the same.

\section{Plasma Glycerol and Ketone Bodies}

Increased plasma levels of glycerol and ketone bodies have been frequently observed after MCT feeding. ${ }^{5,6,25-28}$ In the present study, glycerol concentrations were not significantly elevated after MCT ingestion. Plasma $\beta$-hydroxybutyrate was elevated to moderate levels (400 to 500 $\mathrm{mmol} \cdot \mathrm{L}^{-1}$ ) after MCT ingestion. This may indicate that part of the MCT are metabolized in the liver, resulting in the production of ketone bodies, while the glycerol from hydrolysis of MCT is rapidly utilized for gluconeogenesis.

\section{Substrate Utilization}

We found that MCT ingestion did not affect total CHO or fat utilization. Peak oxidation rates of the oral ingested long-chain glucose polymer were 0.80 to $0.94 \mathrm{~g} \cdot \mathrm{min}^{-1}$, which is in line with previous studies..$^{3,21,32-37}$ Peak oxidation rates of glucose, glucose polymers, and starch have been found to be between 0.8 and $1.0 \mathrm{~g} \cdot \mathrm{min}^{-1}$ with comparable ingestion rate, feeding schedule, and exercise intensity. $2,3,21$ The oxidation rate of orally ingested $\mathrm{CHO}$ seemed to be slightly lower (although not significantly) in the $\mathrm{CHO}+$ MCT trial as compared with $\mathrm{CHO}$ and $\mathrm{HCHO}+\mathrm{MCT}$. The reason for this small difference may be that the amount of $\mathrm{CHO}$ ingested was lower $(149 \vee 214 \mathrm{~g})$. As shown previously, ${ }^{3,37}$ the oxidation rate of orally ingested $\mathrm{CHO}$ did not increase to the same magnitude as the amount of $\mathrm{CHO}$ ingested. The rate of exogenous $\mathrm{CHO}$ oxidation seems to be limited by a yet-undetermined factor. The ingested $\mathrm{CHO}$ contributed $15 \%$ to $25 \%$ to energy expenditure during the 120 - to 180 -minute period. The contribution of MCT to energy expenditure has been shown to be approximately $7 \%$ during the same period (120 to 180 minutes) with similar experimental conditions. ${ }^{5}$

However, according to the literature, the amount of MCT ingested in the present study ( $29 \mathrm{~g}$ ) is reported to be the maximal amount of MCT that can be ingested without causing gastrointestinal problems. ${ }^{27}$

\section{Gastrointestinal Discomfort}

The MCT (29 g) seemed to have no influence on palatability of the beverages. However, since in all tests some such discomfort was reported, this may be attributed to the long-chain glucose polymers that were co-ingested with the MCT. Ivy et $\mathrm{al}^{27}$ reported that administration of 30 g MCT in combination with cereal caused some minor distress in $10 \%$ of the subjects.

In summary, $29 \mathrm{~g}$ MCT co-ingested with CHO during 180 minutes of exercise at $57 \% \mathrm{VO}_{2} \mathrm{max}$ does not influence exogenous or endogenous $\mathrm{CHO}$ utilization or muscle glycogen breakdown.

\section{REFERENCES}

1. Coyle EF, Coggan AR, Hemmert MK, et al: Muscle glycogen utilization during prolonged strenuous exercise when fed carbohydrate. J Appl Physiol 61:165-172, 1986

2. Bosch AN, Dennis SC, Noakes TD: Influence of carbohydrate ingestion on fuel substrate turnover and oxidation during prolonged exercise. J Appl Physiol 76:2364-2372, 1994

3. Wagenmakers AJM, Brouns F, Saris WHM, et al: Oxidation rates of orally ingested carbohydrates during prolonged exercise in man. J Appl Physiol 75:2774-2780, 1993

4. Bach AC, Babayan VK: Medium-chain triglycerides: An update. Am J Clin Nutr 36:950-962, 1982

5. Jeukendrup AE, Saris WHM, Schrauwen P, et al: Metabolic availability of medium chain triglycerides co-ingested with carbohydrates during prolonged exercise. J Appl Physiol 79:756-762, 1995

6. Massicotte D, Péronnet F, Brisson GR, et al: Oxidation of exogenous medium-chain free fatty acids during prolonged exercise-Comparison with glucose. J Appl Physiol 73:1334-1339, 1992

6a. Jeukendrup AE, Saris WHM, Van Diesen R, et al: Effect of endogenous carbohydrate availability on oral medium chain triglyc- eride oxidation during prolonged exercise. J Appl Physiol 80:949954, 1996

7. Beckers EJ, Jeukendrup AE, Brouns F, et al: Gastric emptying of carbohydrate-medium chain triglyceride suspensions at rest. Int J Sports Med 13:581-584, 1992

8. Van Zeyl C, Lambert EV, Noakes TD, et al: Effects of medium-chain triglyceride ingestion on carbohydrate metabolism and cycling performance. Clin Sci 87:30, 1994 (abstr)

9. Costill DL, Coyle E, Dalsky G, et al: Effects of elevated plasma FFA and insulin on muscle glycogen usage during exercise. J Appl Physiol 43:695-699, 1977

10. Hickson RC, Rennie MJ, Conlee RK, et al: Effect of increased plasma fatty acids on glycogen utilization and endurance. J Appl Physiol 43:829-833, 1977

11. Issekutz B, Miller HI, Rodahl K: Lipid and carbohydrate metabolism during exercise. Fed Proc 25:1415-1420, 1966

12. Rennie MJ, Winder WW: A sparing effect of increased plasma fatty acids on muscle and liver glycogen content in the exercising rat. Biochem J 156:647-655, 1976 
13. Vukovich MD, Costill DL, Hickey MS, et al: Effect of fat emulsion infusion and fat feeding on muscle glycogen utilization during cycle exercise. J Appl Physiol 75:1513-1518, 1993

14. Hargreaves M, Kiens B, Richter EA: Effect of increased plasma free fatty acid concentrations on muscle metabolism in exercising men. J Appl Physiol 70:194-201, 1991

15. Randle PJ, Hales CN, Garland PB, et al: The glucose-fatty acid cycle: Its role in insulin sensitivity and the metabolic disturbances of diabetes mellitus. Lancet 1:785-789, 1963

16. Kuipers H, Verstappen FTJ, Keizer HA, et al: Variability of aerobic performance in the laboratory and its physiologic correlates. Int J Sports Med 6:197-201, 1985

17. Gutmann I, Wahlefeld AW: L-(+)-Lactate determination with lactate dehydrogenase and NAD, in Bergmeyer HU: Methods of Enzymatic Analysis (ed 2). New York, NY, Academic, 1974, pp 1464-1468

18. Moore JJ, Marcus M, Sax SM: Kinetic assay of $\beta$-hydroxybutyrate in plasma with COBAS BIO centrifugal analyzer. Clin Chem 73:1334-1339, 1982

19. Passenneau JV, Lauderdaler VR: A comparison of three methods of glycogen measurement in tissue. Anal Biochem 60:404412,1974

20. Péronnet $F$, Massicotte $D$ : Table of nonprotein respiratory quotient: An update. Can J Sport Sci 16:23-29, 1991

21. Saris WHM, Goodpaster BH, Jeukendrup AE, et al: Exogenous carbohydrate oxidation from different carbohydrate sources during exercise. J Appl Physiol 75:2168-2172, 1993

22. Wagenmakers AJM, Rebrer NJ, Brouns F, et al: Breath ${ }^{13} \mathrm{CO}_{2}$ background enrichment at rest and during exercise: Diet related differences between Europe and America. J Appl Physiol 74:2353-2357, 1993

23. Robert JJ, Koziet J, Chauvet D, et al: Use of ${ }^{13} \mathrm{C}$-labeled glucose for estimating glucose oxidation: Some design considerations. J Appl Physiol 63:1725-1732, 1987

24. Dyck DJ, Putman CT, Heigenhauser GJF, et al: Regulation of fat-carbohydrate interaction in skeletal muscle during intense aerobic cycling. Am J Physiol 265:E852-E859, 1993

25. Auclair E, Satabin P, Servan E, et al: Metabolic effects of glucose, medium chain triglyceride and long chain triglyceride feeding before prolonged exercise in rats. Eur $\mathbf{J}$ Appl Physiol $57: 126-131,1988$
26. Decombaz J, Arnaud M-J, Milon H, et al: Energy metabolism of medium chain triglycerides versus carbohydrate during exercise. Eur J Appl Physiol 52:9-14, 1983

27. Ivy JL, Costill DL, Fink WJ, et al: Contribution of medium and long chain triglyceride intake to energy metabolism during prolonged exercise. Int J Sports Med 1:15-20, 1980

28. Satabin P, Portero P, Defer G, et al: Metabolic and hormonal responses to lipid and carbohydrate diets during exercise in man. Med Sci Sports Exerc 19:218-223, 1987

29. Greenberger NJ, Skillman TG: Medium-chain triglycerides: Physiologic considerations and clinical implications. N Engl J Med 280:1045-1058, 1969

30. Metges CC, Wolfram G: Medium- and long-chain triglycerides labeled with ${ }^{13} \mathrm{C}$ : A comparison of oxidation after oral or parenteral administration in humans. J Nutr 121:31-36, 1991

31. Bremer J: Carnitine-metabolism and functions. Physiol Rev 63:1420-1479, 1983

32. Hawley JA, Dennis SC, Nowitz A, et al: Exogenous carbohydrate oxidation from maltose and glucose ingested during prolonged exercise. Eur J Appl Physiol 64:523-527, 1992

33. Leijssen DPC, Saris WHM, Jeukendrup AE, et al: Oxidation of orally ingested $\left[{ }^{13} \mathrm{C}\right]$-glucose and $\left[{ }^{13} \mathrm{C}\right]$-glucose during exercise. $\mathrm{J}$ Appl Physiol 79:720-725, 1995

34. Massicotte D, Péronnet $F$, Allah $C$, et al: Metabolic response to $\left[{ }^{13} \mathrm{C}\right] g l u c o s e$ and $\left[{ }^{13} \mathrm{C}\right]$ fructose ingestion during exercise. J Appl Physiol 61:1180-1184, 1986

35. Moodley D, Noakes TD, Bosch AN, et al: Oxidation of exogenous carbohydrate during prolonged exercise: The effects of the carbohydrate type and its concentration. Eur J Appl Physiol 64:328-334, 1992

36. Pallikarakis N, Jandrain B, Pirnay F, et al: Remarkable metabolic availability of oral glucose during long-duration exercise in humans. J Appl Physiol 60:1035-1042, 1986

37. Rehrer NI, Wagenmakers AJM, Beckers EJ, et al: Gastric emptying, absorption and carbohydrate oxidation during prolonged exercise. J Appl Physiol 72:468-475, 1992

38. Pallikarakis N, Sphiris N, Lefèbvre P: Influence of the bicarbonate pool on the occurrence of ${ }^{13} \mathrm{CO}_{2}$ in exhaled air. Eur $\mathrm{J}$ Appl Physiol 63:179-183, 1991 